\title{
EVOLUTION OF COMMON BEANS COLLECTED FROM LAKE VAN BASIN FOR THEIR RESISTANCE TO THE COMMON BACTERIAL BLIGHT (XANTHOMONAS AXONOPODIS PV. PHASEOLI)
}

\author{
ERDINÇ, Ç. ${ }^{1 *}-$ EKINCIALP, A. ${ }^{2}-$ AKKÖPRÜ, A. ${ }^{3}-$ YILDIZ, M. ${ }^{1}-$ ŞENSOY, S. ${ }^{4}$ \\ ${ }^{1}$ Agricultural Biotechnology Department, Agriculture Faculty, Van Yuzuncu Yil University \\ 65080 Van, Turkey \\ ${ }^{2}$ Baskale Vocational School, Van Yuzuncu Yil University, 65080 Van, Turkey \\ ${ }^{3}$ Plant Protection Department, Agriculture Faculty, Van Yuzuncu Yil University \\ 65080 Van, Turkey
}

${ }^{4}$ Horticulture Department, Agriculture Faculty, Van Yuzuncu Yil University, 65080 Van, Turkey

*Corresponding author

e-mail: ceknaserdinc@gmail.com; phone: +90-432-225-1024

(Received $1^{\text {st }}$ Jun 2018; accepted $31^{\text {st }}$ Jul 2018)

\begin{abstract}
The present study determined the reactions of common bean landraces grown in Lake Van Basin of Turkey against common bacterial blight disease (CBB) caused by Xanthomonas axonopodis pv. phaseoli (Xap). For this purpose 83 bean landraces collected from the basin and two resistant (HR-45, HR-67) and one susceptible (Dresden) lines were evaluated for their reaction to Xap. The experiments were conducted in randomized experimental design with three replications in a growth chamber having $23 \pm 2{ }^{\circ} \mathrm{C}$ temperature and $16 \mathrm{~h}$ light $8 \mathrm{~h}$ dark period. Bean seeds were sown in the pots having 2:1 mixture of peat:perlite and Xap inoculated by spraying when the seedlings reached two trifoliate leaves stage. Disease severity was assessed three weeks after Xph inoculation using 1-5 scale. In light of the findings, it was detected that there was a variation with regard to tolerance to the disease among common bean landraces. While fourteen landraces were assigned as resistant against CBB, 49 landraces were found to be moderately susceptible to $\mathrm{CBB}$. The present study demonstrated the existence of resistance sources against $\mathrm{CBB}$ within Lake Van Basin bean landraces that could potentially be used for breeding resistant cultivars.
\end{abstract}

Keywords: disease, Phaseolus vulgaris L., landraces, Xap, artificial inoculation

\section{Introduction}

Common bean is among the most widely grown species in the world and have been grown widespread in Turkey due to economical and nutritional aspects. It is originated in South and Central America (including Mexica, Guatemala, Colombia, and Peru) and has been cultivated since $5000 \mathrm{BC}$. Common bean has a wide distribution area from sea level to $3000 \mathrm{~m}$ altitude (Şalk et al., 2008; Koutsika-Sotiriou and Traka-Mavrona, 2008). While China is the first fresh bean producer in world, Turkey ranks fourth with 651.094 tons meeting about $2.75 \%$ of the world production (FAO, 2016). There has been a large variability in common bean having a widespread distribution in Turkey (Erdinc et al., 2013, 2017a, b). Common bean ranks third in the world in terms of importance in Fabaceae (Blair et al., 2009). It reported that besides common bean supplies $30 \%$ need of protein, it helps to fight many diseases because of the antioxidant 
compounds it contains. Additionally common bean has been used cosmetic and paint industry (Singh et al., 2007).

Many abiotic and biotic stress factors have caused problems in common bean. Common bacterial blight (CBB) is one of the major seed-borne diseases which give rise to yield and quality losses and is caused by Xanthomonas axonopodis pv. phaseoli (Xap). Pathogen shows its detrimental effects in tropical, subtropical and temperate regions (Vandemark et al., 2008). Seed is a very significant factor in the spread of Xph because the viability of the pathogen can be maintained 30 years on the seed (Dursun et al., 2002; Shi et al., 2011a), sometimes leads to yield losses exceeding 40\% (Vandemark et al., 2008). There is no satisfactory chemical control for CBB and usage of the resistant cultivars is one of the most effective and environmentalist approaches (Opio et al., 1996; Park et al., 1999).

It is indicated that CBB is a common threat today on all continents where grown common bean. In Turkey, it was determined first time by Sönmezalp in 1966. Xap was also identified in Nigde, Kayseri and Yozgat provinces and in some areas of East Anatolia (Bozkurt, 2009).

The climate of the Lake Van Basin differs from the cold Eastern Turkey where it is located. The basin has a microclimate which allows for production vegetable including common bean etc. (Erdinc et al., 2008). The province of Van is located between $37^{\circ} 55^{\prime}$ and $39^{\circ} 24^{\prime}$ north longitude and $42^{\circ} 05^{\prime}$ and $44^{\circ} 22^{\prime}$ east latitude and at an altitude of $1720 \mathrm{~m}$ above sea level. It has a continental climate. Comparatively rich genetic diversity was found among the Lake Van Basin common bean population by phenotypic and molecular markers (Ekincialp, 2012).

Many researchers reported that the resistance to Xap was managed by a dominant gene (Drijfhout and Blok, 1987; Silva et al., 1989; Urrea et al., 1999; Zapata et al., 2011). Resistance to CBB in common bean has been reported as a quantitative trait with low to medium heritability (Silva et al., 1989), conditioned by 1-5 genes with additive gene action (Tar'an et al., 2001). Therefore, screening of genetic resources of the region and providing the resistant or tolerant landraces in breeding programs by determining reactions against the disease of genetic material is important in development of resistant cultivars.

\section{Material and methods}

\section{Plant materials and pathogen}

Eighty two landraces of common bean and one runner bean genotype (G30) collected from Lake Van Basin of Turkey (Ekincialp, 2012), two resistant (HR-45 and HR-67) (Yu et al., 2004; Gillard et al., 2009; Shi et al., 2011a, b, 2012) and one susceptible lines (Dresden) (Shi et al., 2011a, 2012) from Dr. Ali Reza NAVABİ was used in the present study (Table 1). Xap isolate was obtained from Prof. Dr. Hüseyin BASIM (Akdeniz University, Agriculture Faculty, Department of Plant Protection).

\section{Pathogenicity assays}

In the first artificial inoculation trial, the eighty-three bean landraces and control lines (HR-45, HR-67 and Dresden) were tested against Xap, then based on the results, twelve landraces with control lines were selected for the second trial. Common bean seeds was sown to the pots including 2:1 mixture of peat:perlit in a randomized 
experimental design with three replications in a chamber growth having $23 \pm 2{ }^{\circ} \mathrm{C}$ temperature and $16 \mathrm{~h}$ light- $8 \mathrm{~h}$ dark period.

Table 1. Passport information of the genotype used in the study

\begin{tabular}{|c|c|c|c|c|c|}
\hline Accession & Location & Grow habit & Accession & Location & Grow habit \\
\hline G1 & Van-Merkez & Indeterminate & G46 & Van-Gevaş & Indeterminate \\
\hline G2 & Van-Merkez & Indeterminate & G47 & Van-Gevaş & Indeterminate \\
\hline G3 & Van-Merkez & Indeterminate & $\mathrm{G} 48$ & Van-Gevaş & Indeterminate \\
\hline G4 & Van-Merkez & Indeterminate & G49 & Van-Gevaş & Indeterminate \\
\hline G5 & Bitlis-Tatvan & Indeterminate & G-50 & Van-Gevaş & Indeterminate \\
\hline G6 & Bitlis-Tatvan & Indeterminate & G-51 & Van-Gevaş & Indeterminate \\
\hline G7 & Bitlis-Tatvan-Gevar & Indeterminate & G-52 & Van-Gevaş & Indeterminate \\
\hline G8 & Bitlis-Tatvan & Indeterminate & G-53 & Van-Gevaş & Indeterminate \\
\hline G9 & Bitlis-Hizan & Indeterminate & G-55 & Van-Gevaş & Indeterminate \\
\hline G10 & Bitlis-Tatvan-Gevar & Indeterminate & G-57 & Van-Gevaş & Indeterminate \\
\hline G11 & Bitlis-Hizan & Determinate & G-58 & Van-Gevaş & Indeterminate \\
\hline G12 & Bitlis-Tatvan & Indeterminate & G-59 & Van-Gevaş & Determinate \\
\hline G13 & Bitlis-Tatvan & Indeterminate & G-60 & Van-Gevaş & Indeterminate \\
\hline G14 & Bitlis-Tatvan & Indeterminate & G-61 & Van-Gevaş & Indeterminate \\
\hline G15 & Bitlis-Tatvan & Indeterminate & G-62 & Van-Gevaş & Determinate \\
\hline G16 & Bitlis-Tatvan & Indeterminate & G-63 & Bitlis-Adilcevaz & Indeterminate \\
\hline G17 & Bitlis-Tatvan & Indeterminate & G-64 & Bitlis-Adilcevaz & Indeterminate \\
\hline G18 & Van-Erciş-Purmak & Indeterminate & G-65 & Bitlis- Adilcevaz & Indeterminate \\
\hline G19 & Van-Erciş-Çelebibağ 1 & Indeterminate & G-66 & Bitlis- Adilcevaz & Indeterminate \\
\hline G20 & Van-Erciş & Indeterminate & G-67 & Bitlis- Adilcevaz & Indeterminate \\
\hline G21 & Van-Erciş-Tekevler & Indeterminate & G-68 & Bitlis- Adilcevaz & Indeterminate \\
\hline G22 & Van-Erciş-Tekevler & Indeterminate & G-70 & Bitlis- Adilcevaz & Indeterminate \\
\hline $\mathrm{G} 23$ & Van-Erciş-Tekevler & Indeterminate & G-71 & Bitlis- Adilcevaz & Determinate \\
\hline G24 & Van-Erciş-Tekevler & Indeterminate & G-72 & Bitlis- Adilcevaz & Indeterminate \\
\hline $\mathrm{G} 25$ & Van-Erciş-Tekevler & Indeterminate & G-73 & Bitlis-Adilcevaz & Indeterminate \\
\hline G26 & Van-Erciş & Indeterminate & G-74 & Bitlis-Adilcevaz & Indeterminate \\
\hline G27 & Van-Erciş & Indeterminate & G-75 & Bitlis-Adilcevaz & Indeterminate \\
\hline G28 & Van-Erciş & Indeterminate & G-76 & Bitlis-Adilcevaz & Determinate \\
\hline G29 & Van-Gevaş-G.konak & Determinate & G-77 & Bitlis-Adilcevaz & Determinate \\
\hline G30 & Van-Gevaş (P. coccineus) & Indeterminate & G-78 & Bitlis-Adilcevaz & Determinate \\
\hline G31 & Van-Gevaş & Indeterminate & G-90 & Van-Edremit & Indeterminate \\
\hline G32 & Van-Gevaş & Indeterminate & G-91 & Van-Edremit & Indeterminate \\
\hline G33 & Van-Gevaş & Indeterminate & G-92 & Van-Edremit & Indeterminate \\
\hline G34 & Van-Gevaş & Indeterminate & G-93 & Van-Edremit & Indeterminate \\
\hline G35 & Van-Gevaş & Indeterminate & G-94 & Van-Edremit & Indeterminate \\
\hline G36 & Van-Gevaş & Indeterminate & G-95 & Van-Bahçesaray & Determinate \\
\hline G37 & Van-Gevaş & Indeterminate & G-96 & Van-Bahçesaray & Indeterminate \\
\hline G39 & Van-Gevaş & Indeterminate & G-97 & Van-Bahçesaray & Indeterminate \\
\hline G40 & Van-Gevaş & Indeterminate & G-98 & Van-Bahçesaray & Indeterminate \\
\hline G41 & Van-Gevaş & Indeterminate & G-99 & Van-Bahçesaray & Indeterminate \\
\hline G42 & Van-Gevaş & Indeterminate & HR-45 & Canada & Determinate \\
\hline G43 & Van-Gevaş & Indeterminate & HR-67 & Canada & Determinate \\
\hline G44 & Van-Gevaş & Indeterminate & Dresden & Canada & Determinate \\
\hline
\end{tabular}


Xap isolate was inoculated to the bean seedlings with two trifoliate leaves. In this stage, Xph grown on KB medium King B (pepton $20 \mathrm{~g} / \mathrm{L}$, gliserol $10 \mathrm{ml} / \mathrm{L}, \mathrm{K}_{2} \mathrm{HPO}_{4}$ $1.5 \mathrm{~g} / \mathrm{L}, \mathrm{MgSO}_{4} . / \mathrm{H}_{2} \mathrm{O} 1.5 \mathrm{~g} / \mathrm{L}$, agar $18 \mathrm{~g} / \mathrm{L}$ ) at $28{ }^{\circ} \mathrm{C}$ for $48 \mathrm{~h}$. (King and Raney, 1954) and then the grown Xph colonies were suspended in distilled water and adjusted to $10^{8}$ cfu $\mathrm{ml}^{-1}(\mathrm{OD}=0.13)$ (Osdaghi et al., 2009). The bacterial mixture was spread onto 15 days old common bean seedlings with fully expanded trifoliate leaves. The benches with pots were covered with polyethylene sheet for providing moisture to favor development of $C B B$. After $48 \mathrm{~h}$, the covers were opened. Plants were irrigated weekly including Hoagland nutrient solution. In twenty-first days after inoculation, CBB symptoms in the plants were assessed using 1-5 scale (Table 2) which was modified for this study and the disease severity was determined with Townsend-Heuberger equation (Townsend and Heuberger, 1943).

The disease severity was calculated using the following formula:

$$
\text { Disease severity }=\frac{\sum \text { (Rating number } x \text { Number of leaves in the rating) }}{\text { Total number of leaves } x \text { Highest rating }} \times 100
$$

Table 2. The values of 1-5 scale that was used to determine the disease severity of Xap in the bean landraces

\begin{tabular}{c|c}
\hline Scale value & Statement \\
\hline 1 & No visible symptom \\
2 & Necrosis in 1-5\% of leaf or single spots \\
3 & Necrosis in $6-25 \%$ of leaf \\
4 & Necrosis in $26-50 \%$ of leaf \\
5 & Necrosis in leaf more than 50\% or plant death \\
\hline
\end{tabular}

As a result of calculating of the scale values, the landraces were assigned as $<2$ : resistant, <3: moderately susceptible, <4: susceptible, <5: extreme susceptible (Dursun et al., 2002; Osdaghi et al., 2009). In the both artificial inoculation trials, the data were analyzed using the statistical software package SPSS. The means were grouped using the Duncan multiple comparison test (Düzgüneş et al., 1987)

\section{Results and discussion}

\section{First artificial inoculation trial}

The results of the first artificial inoculation are given in Table 3. In the result of the analysis of variance, it was found that the differences between the landraces were significant $(\mathrm{p}<0.05)$. According to the results obtained, 14 of the landraces were scaled to 1-2 and rated as resistant to CBB and the genotype G99 was the most resistant genotype with a scale value of 1.42. The great majority of landraces (49 landraces) was ranged from 2 to 3 and was found to be moderately susceptible to CBB. It was also determined that 19 landraces were susceptible and their disease severity scales were varied from 3 to 4 . The genotype G37 was the most susceptible one with a scale value of 4.32. Two resistant (HR-45 and HR-67) control lines were found to have lower scale values than the studied bean landraces and the susceptible line, Dresden, was found to 
be in the group of sensitive landraces with a score of 3.29 (Table 3). When frequency distribution according to disease scale values were examined, $18.60 \%$ of the landraces including control lines were found to be resistant, $63.96 \%$ of them were moderately susceptible, $16.28 \%$ of them were susceptible and $1.17 \%$ of them were very susceptible (Fig. 1).

Table 3. The disease severity values of first artificial inoculation in the bean landraces calculated according to Townsend-Heuberger equation

\begin{tabular}{|c|c|c|c|c|c|c|c|c|}
\hline $\begin{array}{c}\text { Accession } \\
\#\end{array}$ & $\begin{array}{l}\text { Scale } \\
\text { value }\end{array}$ & $\begin{array}{l}\text { Disease } \\
\text { response }\end{array}$ & $\begin{array}{c}\text { Accession } \\
\#\end{array}$ & $\begin{array}{l}\text { Scale } \\
\text { value }\end{array}$ & $\begin{array}{l}\text { Disease } \\
\text { response }\end{array}$ & $\begin{array}{c}\text { Accession } \\
\#\end{array}$ & $\begin{array}{l}\text { Scale } \\
\text { value }\end{array}$ & $\begin{array}{l}\text { Disease } \\
\text { response }\end{array}$ \\
\hline G1 & 1.86 C-J* & $\mathrm{R}$ & G30 & 1.73 D-J & $\mathrm{R}$ & G63 & $1.84 \mathrm{C}-\mathrm{J}$ & $\mathrm{R}$ \\
\hline G2 & 2.18 B-J & MS & G31 & $2.69 \mathrm{~A}-\mathrm{J}$ & MS & G64 & 3.07 A-I & $S$ \\
\hline G3 & 1.75 D-J & $\mathrm{R}$ & G32 & $1.00 \mathrm{~J}$ & $\mathrm{R}$ & G65 & 2.47 A-J & MS \\
\hline G4 & 2.07 B-J & MS & G33 & 2.17 B-J & MS & G66 & $3.25 \mathrm{~A}-\mathrm{H}$ & S \\
\hline G5 & 1.65 F-J & $\mathrm{R}$ & G34 & 1.75 D-J & $\mathrm{R}$ & G67 & 2.19 B-J & MS \\
\hline G6 & 2.79 A-J & MS & G35 & $1.82 \mathrm{C}-\mathrm{J}$ & $\mathrm{R}$ & G68 & $2.58 \mathrm{~A}-\mathrm{J}$ & MS \\
\hline G7 & 2.36 B-J & MS & G36 & $3.41 \mathrm{~A}-\mathrm{F}$ & $S$ & G70 & 2.55 A-J & MS \\
\hline G8 & 1.72 D-J & $\mathrm{R}$ & G37 & $4.32 \mathrm{~A}$ & HS & G71 & 2.27 B-J & MS \\
\hline G9 & $2.16 \mathrm{~B}-\mathrm{J}$ & MS & G39 & $2.42 \mathrm{~B}-\mathrm{J}$ & MS & G72 & $3.02 \mathrm{~A}-\mathrm{I}$ & $S$ \\
\hline G10 & 2.12 B-J & MS & G40 & $3.49 \mathrm{~A}-\mathrm{F}$ & $S$ & G73 & $3.01 \mathrm{~A}-\mathrm{I}$ & $S$ \\
\hline G11 & 2.07 B-J & MS & G41 & 2.84 A-J & MS & G74 & $2.38 \mathrm{~B}-\mathrm{J}$ & MS \\
\hline G12 & $1.69 \mathrm{E}-\mathrm{J}$ & $\mathrm{R}$ & G42 & $3.10 \mathrm{~A}-\mathrm{I}$ & S & G75 & $3.90 \mathrm{AB}$ & S \\
\hline G13 & $2.41 \mathrm{~B}-\mathrm{J}$ & MS & G43 & $2.35 \mathrm{~B}-\mathrm{J}$ & MS & G76 & $2.38 \mathrm{~B}-\mathrm{J}$ & MS \\
\hline G14 & 2.28 B-J & MS & G44 & $2.80 \mathrm{~A}-\mathrm{J}$ & MS & G77 & 3.19 A-I & S \\
\hline G15 & $2.26 \mathrm{~B}-\mathrm{J}$ & MS & G46 & $2.81 \mathrm{~A}-\mathrm{J}$ & MS & G78 & $3.01 \mathrm{~A}-\mathrm{I}$ & $S$ \\
\hline G16 & $2.22 \mathrm{~B}-\mathrm{J}$ & MS & G47 & $3.01 \mathrm{~A}-\mathrm{I}$ & $S$ & G90 & $2.29 \mathrm{~B}-\mathrm{J}$ & MS \\
\hline G17 & 2.45 B-J & MS & G48 & 2.44 B-J & MS & G91 & $3.49 \mathrm{~A}-\mathrm{F}$ & $S$ \\
\hline G18 & 2.45 B-J & MS & G49 & $2.73 \mathrm{~A}-\mathrm{J}$ & MS & G92 & 2.48 A-J & MS \\
\hline G19 & 2.62 A-J & MS & G-50 & $2.56 \mathrm{~A}-\mathrm{J}$ & MS & G93 & 2.40 B-J & MS \\
\hline G20 & 1.95 C-J & $\mathrm{R}$ & G-51 & 2.35 B-J & MS & G94 & $3.53 \mathrm{~A}-\mathrm{E}$ & S \\
\hline G21 & 2.72 A-J & MS & G-52 & $2.91 \mathrm{~A}-\mathrm{I}$ & MS & G95 & 2.47 A-J & MS \\
\hline G22 & 2.47 A-J & MS & G-53 & $3.89 \mathrm{AB}$ & S & G96 & $3.67 \mathrm{~A}-\mathrm{C}$ & S \\
\hline G23 & $3.01 \mathrm{~A}-\mathrm{I}$ & S & G-55 & $3.10 \mathrm{~A}-\mathrm{I}$ & S & G97 & 2.09 B-J & MS \\
\hline G24 & 3.59 A-D & S & G-57 & $2.87 \mathrm{~A}-\mathrm{J}$ & MS & G98 & $2.25 \mathrm{~B}-\mathrm{J}$ & MS \\
\hline G25 & 1.97 C-J & $\mathrm{R}$ & G-58 & $3.02 \mathrm{~A}-\mathrm{I}$ & S & G99 & 1.42 G-J & $\mathrm{R}$ \\
\hline G26 & $2.26 \mathrm{~B}-\mathrm{J}$ & MS & G-59 & 2.49 A-J & MS & HR-45 & $1.40 \mathrm{H}-\mathrm{J}$ & $\mathrm{R}$ \\
\hline G27 & $1.93 \mathrm{C}-\mathrm{J}$ & $\mathrm{R}$ & G-60 & $2.29 \mathrm{~B}-\mathrm{J}$ & MS & HR-67 & $1.34 \mathrm{IJ}$ & $\mathrm{R}$ \\
\hline G28 & $2.23 \mathrm{~B}-\mathrm{J}$ & MS & G-61 & 2.09 B-J & MS & Dresden & $3.29 \mathrm{~A}-\mathrm{G}$ & $S$ \\
\hline G29 & 2.94 A-I & MS & G-62 & 2.05 B-J & MS & & & \\
\hline
\end{tabular}

*There were significant differences among the different letter(s) at $\mathrm{P}<0.05$ level (according to Duncan's multiple comparison test). R: Resistant, MS: Moderately susceptible, S: Susceptible, HS: High susceptible 


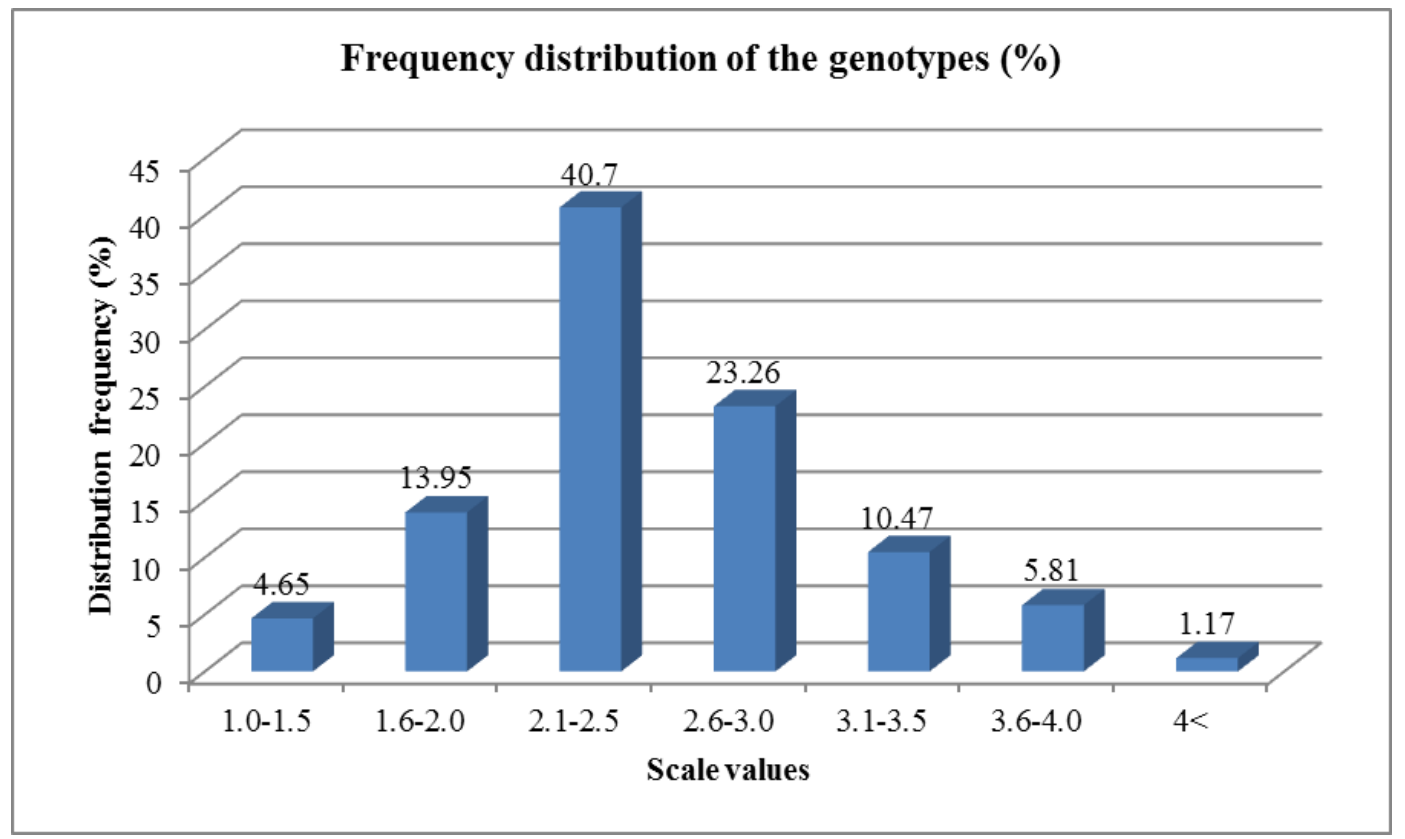

Figure 1. Distribution frequency (\%) of reaction to CBB of the bean landraces according to scale values

\section{Second artificial inoculation trial}

Based on the first artificial inoculation trial, twelve landraces resistant to CBB with sufficient number of seeds (the landraces G12 and G32 were excluded) were artificially re-inoculated. Resistant (HR-45 and HR-67) and sensitive (Dresden) lines were also used for control in the second trial. When the disease severity values obtained at the end of the trial were examined, it was determined that the landraces had a scale value of 1-2 and showed resistance. It was determined that the lowest value of the landraces was 1.27 (in the genotype G27), while the highest value was found in the landraces G35 and G63 with 1.83. It was also found that the HR-45 and HR-67 lines reached lower scale values than the other landraces (scale values of 1.11 and 1.00, respectively). As a result of the analysis of variance, it was found that the differences between the landraces were statistically significant $(p<0.05)$. Disease severity reactions of the resistant landraces have generally been observed to be similar to each other in both studies (Fig. 2).

Xap, among the most important seed-borne bacterial pathogens in bean (Bastas and Sahin, 2017), is also among the serious bacterial diseases causing yield and quality loses in Turkey (Demir and Gündogdu, 1994; Donmez, 2004). In surveys conducted in the Central Anatolia Region, Xap was reported to be among the most common bacterial pathogens with $11.11 \%$ of presence (Bastas and Sahin, 2017).

In current study, the severity of disease in artificial inoculation was evaluated after 21 days in both studies. As a matter of fact, Marquez et al. (2007) reported that even if an aggressive isolate is used, classifications that would have been made by previous evaluations on 14 days might be erroneous.

It has been determined that there is a variation in the reactions of the bean landraces to BCC. As a matter of fact, according to Ekincialp (2012), there is a high genetic variation in the morphological and molecular characterization studies carried out among these landraces. The landraces G30, G37, and G53 which are morphologically and 
genetically most distant from each other, have also been found to differ in their CBB disease reactions, while G30 is resistant and G53 is susceptible and G37 is highly susceptible. It has also been reported that the G30 genotype ( $P$. coccineus) is differentiated from other landraces in terms of general habitus and morphological characteristics (number of flower buds in the cluster, seed width, seed length, seed height and seed weight) (Ekincialp, 2012).

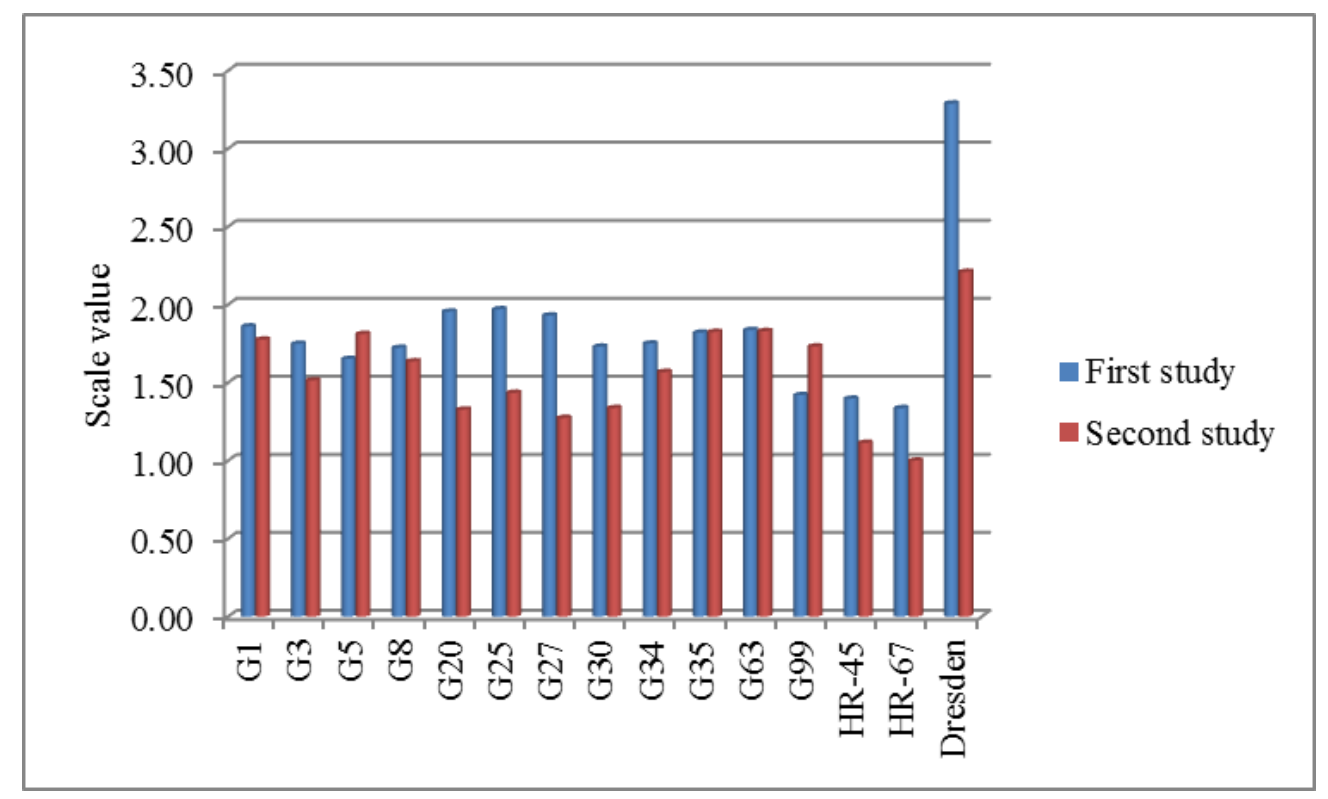

Figure 2. Reactions of the bean landraces were classified as resistant based on 1-5 scale in artificial inoculation method for CBB in first and second trials

It was noticed that the landraces G12 and G30 that were resistant to bean anthracnose (Ekincialp and Sensoy, 2018) were also resistant to CBB in the present study. Moreover, all landraces susceptible to $\mathrm{CBB}$ have been found to be susceptible to anthracnose disease. It was observed that the G30 genotype belonging to $P$. coccineus was present in a group of resistant landraces in both studies. It is generally stated that $P$. coccineus (runner bean) has similar or higher resistance level as P. vulgaris, P. acutifolius (tepary bean) shows the highest level of resistance (Drijfhout and Blok, 1987; Singh and Munoz, 1999).

The results of the landraces used for control purposes during pathogenicity tests are shown in Table 3 and 4. As seen in the tables, the reactions of these landraces to the disease were determined as resistant (R) in HR-45 and HR-67 sensitive (S) in Dresden. It was also reported in the literature that HR-45 and HR-67 were resistant to Xap (Yu et al., 2004; Gillard et al., 2009; Shi et al., 2011 a, b, 2012) and Dresden was susceptible to XAP Shi et al., 2011a, 2012).

In the present study, a large number of bean landraces were screened and approximately $17 \%$ of them was found to be resistant to Xap (Table 3; Fig. 3). Halo blight and common blight screening studies were conducted in beans in different regions of Turkey; it was demonstrated that some landraces were resistance to halo blight (Benlioglu et al., 1994; Dursun et al., 2002) and only one variety was resistant to common blight (Dursun et al., 2002). It was determined that $50 \%$ of the landraces used in the mentioned studies were highly susceptible. Osdaghi et al. (2009) determined that 
two of the 30 cultivars/lines were resistant to CBB. On the contrary, Fininsa and Tefera (2006) reported that 117 out of 201 landraces (approximately 58\%) in Ethiopia were resistant to $\mathrm{CBB}$.

Table 4. Disease severity of second artificial inoculation in the bean landraces

\begin{tabular}{c|c}
\hline Accessions \# & Scale value \\
\hline G1 & 1.78 B* \\
G3 & $1.51 \mathrm{~B}-\mathrm{E}$ \\
G5 & $1.81 \mathrm{AB}$ \\
G8 & $1.64 \mathrm{~B}-\mathrm{D}$ \\
G20 & $1.33 \mathrm{C}-\mathrm{F}$ \\
G25 & $1.44 \mathrm{~B}-\mathrm{E}$ \\
G27 & $1.27 \mathrm{D}-\mathrm{F}$ \\
G30 & $1.34 \mathrm{C}-\mathrm{F}$ \\
G34 & $1.57 \mathrm{~B}-\mathrm{D}$ \\
G35 & $1.83 \mathrm{AB}$ \\
G63 & $1.83 \mathrm{AB}$ \\
G99 & $1.73 \mathrm{BC}$ \\
HR-45 & $1.11 \mathrm{EF}$ \\
HR-67 & $1.00 \mathrm{~F}$ \\
Dresden & $2.21 \mathrm{~A}$ \\
\hline p value & 0.001 \\
\hline
\end{tabular}

*There were significant differences among the different letter(s) at $\mathrm{P}<0.05$ level (according to Duncan's multiple comparison test)

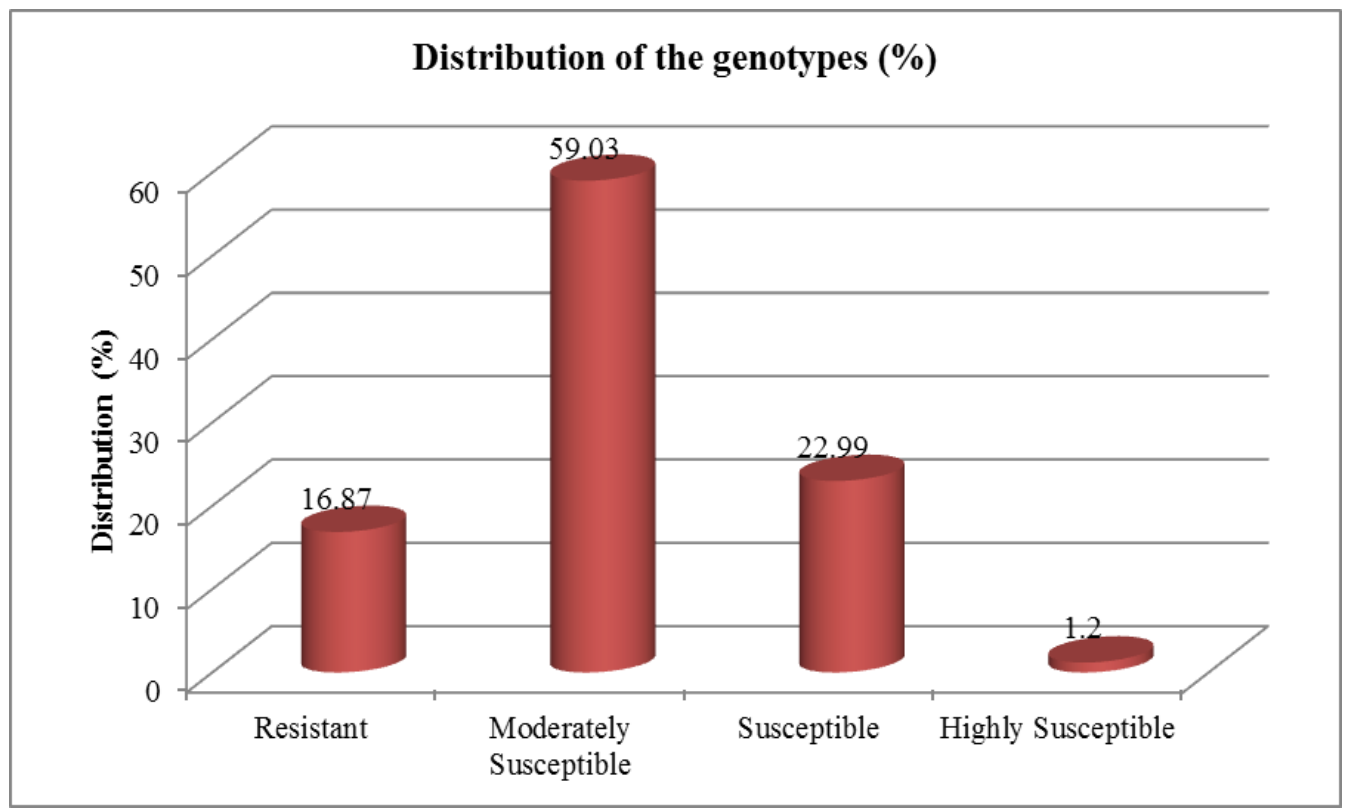

Figure 3. Distribution of the landraces excluding control lines according to disease response 


\section{Conclusions}

Turkey is an important country in the production of green beans and meets $3 \%$ of the world production. Maintaining or advancing the current position will be through the development of highly productive, tolerant varieties that can meet consumer and producer demands. In the present study, the resistance status of bean landraces collected from Lake Van Basin, which is an important potential for vegetable production in the region, is revealed. From this point of view, it is noticed that there is a source of resistance. Resistant landraces are expected to be used as parents in bean improvement programs in the future. Considering the efforts of countries in recent years to protect their local gene resources, this situation is better understood. This is the first study and report of resistance against CBB in Lake Van Basin bean landraces. The present study demonstrated the existence of resistance sources against $\mathrm{CBB}$ within them that could potentially be used for breeding resistant cultivars.

Acknowledgements. This study was funded by the project \# 2013-ZF-B032 of Scientific Research Projects Council of Van Yuzuncu Yil University. We would like to thank Prof. Dr. Alireza NAVABI and Prof. Dr. Hüseyin BASIM for their material supply.

\section{REFERENCES}

[1] Bastas, K. K., Sahin, F. (2017): Evaluation of seedborne bacterial pathogens on common bean cultivars grown in central Anatolia region, Turkey. - Eur. J. Plant Pathol 147: 239253.

[2] Benlioglu, K., Ozakman, M., Onceler, Z. (1994): Bacterial blight of beans in Turkey and resistance to halo blight and common blight: - 9th Congress of the Mediterranean Phytopathological Union, September 18-24 1994, Kusadas1, Aydın, pp. 547-550.

[3] Blair, M. W., Diaz, L. M., Buendia, H. F., Duque, M. C. (2009): Genetic diversity, seed size associations and population structure of a core collection of common beans (Phaseolus vulgaris L.). - Theor. Appl. Genet. 119: 955-972.

[4] Bozkurt, A. (2009): The control possibilities against bean common blight (Xanthomonas axonopodis pv. phaseoli) with antogonistic bacteria. - Ph.D. Thesis, Ege University.

[5] Demir, G., Gündogdu, M. (1994): Bacterial diseases of food legumes in aegean region of turkey and effectivity of some seed treatments against bean halo blight. - Journal of Turkish Phytopathology 23: 57-66.

[6] Donmez, M. F. (2004): Determination of resistance against bacterial pathogens in various bean genotypes (Phaseolus vulgaris L.) grown in the provinces of Erzurum and Erzincan. - Ph.D. Thesis, Ataturk University.

[7] Drijfhout, E. W., Blok, J. (1987): Inheritance of resistance to Xanthomonas campestris pv. phaseoli in tetary bean (Phaseolus acutifolius). - Euphytica 36: 803-808.

[8] Dursun, A.,. Dönmez, M. F., Şahin, F. (2002): Identification of resistance to common bacterial blight disease on bean genotypes grown in Turkey. - European Journal of Plant Pathology 108: 811-813.

[9] Düzgüneş, O., Kesici, T., Kavuncu, O., Gürbüz, F. (1987): Araştırma ve Deneme Metotları. - Ankara Üniversitesi, Ziraat Fakültesi Yayınları, Ankara.

[10] Ekincialp, A. (2012): Determination of Genetic Relatedness and Anthracnose Disease (Colletotrichum lindemuthianum) (Sacc. \& Magnus) Lambs. Scrib.) Resistance with phenotypic and molecular methods among bean genotypes in Lake Van Basin. - Ph.D. Thesis, Yuzuncu Yil University. 
[11] Ekincialp, A., Şensoy, S. (2018): Phenotypic and molecular determination of anthracnose disease resistance in Lake Van Basin's bean genotypes (Phaseolus vulgaris L.). Legume Research 41(1): 135-142.

[12] Erdinc, C., Turkmen, O., Sensoy, S. (2008): Comparison of some local melon genotypes selected from Lake Van Basin with some commercial melon cultivars for some yield and quality related traits observed in field and high tunnel conditions. - African Journal of Biotechnology 7(22): 4105-4110.

[13] Erdinc, C., Turkmen, O., Sensoy, S. (2013): Determination of various vegetative characteristic of some bean genotypes of Turkey. - YYU. J. Agr. Sci. 23(2): 112-125.

[14] Erdinc, C., Turkmen, O., Dasgan, H. Y., Sensoy, S. (2017a): Phenotypic and molecular genetic diversity among some Turkish bean genotypes. - Journal of Animal and Plant Sciences 27(6): 1963-1973.

[15] Erdinc, C., Turkmen, O., Demir, S., Sensoy, S. (2017b): Determination of the anthracnose (Colletotrichum lindemuthianum (Sacc. And Magn.) Lambs. Scrib.) resistance in some Turkish bean genotypes by artificial inoculation and molecular methods. - Journal of Animal and Plant Sciences 27(1): 175-185.

[16] FAO (2016): FAOSTAT. Statistic Database. - http://faostat.fao.org/.

[17] Fininsa, C., Tefera, T. (2006): Multiple disease resistance in common bean genotypes and their agronomic performance in eastern Ethiopia. - International Journal of Pest Management 52(4): 291-296.

[18] Gillard, C. L., Conner, R. L., Howard, R. J., Pauls, K. P., Shaw, L., Taran, B. (2009): The performance of dry bean cultivars with and without common bacterial blight resistance in field studies across Canada. - Can. J. Plant Sci 89: 405-410.

[19] King, E. O., Ward, M. K., Raney, D. E. (1954): Two simple media for the demonstration of pyocyanin and fluorescein. - J. Clin. Med 44: 301-307.

[20] Koutsika-Sotiriou, M., Traka-Mavrona, E. (2008): Snap Bean. - In: Prohens, J., Nuez, F. (eds.) Vegetables II (Fabaceae, Liliaceae, Solanaceae and Umbelliferae). Springer Science, Business Media LLC, New York.

[21] Marquez, L. M., Teran, H., Singh, S. P. (2007): Selecting Common Bean with Genes of Diff erent Evolutionary Origins for Resistance to Xanthomonas campestris pv. phaseoli. - Crop Sci 47: 1367-1374.

[22] Opio, A. F., Allen, D. J., Teri, J. M. (1996): Pathogenic variation in Xanthomonas campestris pv. phaseoli, the causal agent of common bacterial blight in Phaseolus beans. - Plant Pathology 45: 1126-1133.

[23] Osdaghi, E., Alizadeh, A., Shams-Bakhsh, M., Reza Lak, M. (2009): Evaluation of common bean lines for their reaction to the common bacterial blight pathogen. Phytopathol. Mediterr. 48: 461-468.

[24] Park, S. J., Rupert, T., Anderson, T. R. (1999): White mold: germplasm screening under various field conditions in Ontario. - Annual Report of the Bean Improvement Cooperative 42: 51-52.

[25] Salk, A., Arın, L., Deveci, M., Polat, S. (2008): Özel Sebzecilik. - Namık Kemal Üniversitesi, Ziraat Fakültesi, Bahçe Bitkileri Bölümü, Tekirdağ.

[26] Shi, C., Chaudhary, S., Yu, K., Park, S., Navabi, A., McClean, P. (2011a): Identification of candidate genes associated with $\mathrm{CBB}$ resistance in common bean HR45 (Phaseolus vulgaris L.) using cDNA-AFLP. - Mol Biol Rep 38: 75-81.

[27] Shi, C., Navabi, A., Yu, K. (2011b): Association mapping of common bacterial blight resistance QTL in Ontario bean breeding populations. - BMC Plant Biology 11: 52.

[28] Shi, C., Yu, K., Xie, W., Perry, G., Navabi, A., Pauls, K. P., Miklas, P. N., Deidre, F. (2012): Development of candidate gene markers associated to common bacterial blight resistance in common bean. - Theor. Appl. Genet. 125: 1525-1537.

[29] Silva, L. O.,. Singh, S. P., Pastor-Corrales, M. A. (1989): Inheritance of resistance to bacterial blight in common bean. - Theor. Appl. Genet. 78: 619-624. 
[30] Singh, R. J., Chung, G. H., Nelson, R. L. (2007): Landmark research in Legumes. Genome 50: 525-537.

[31] Singh, S. P., Munoz, C. G. (1999): Resistance to common bacterial blight among Phaseolus species and common bean improvement. - Crop Sci 39: 80-89.

[32] Tar'An, B., Michaels, T. E., Pauls, K. P. (2001): Mapping genetic factors affecting the reaction to Xanthomonas axonopodis pv. phaseoli in Phaseolus vulgaris L. under field conditions. - Genome 44(6): 1046-1056.

[33] Townsend, G. R., Heuberger, J. V. (1943): Methods for estimating losses caused by diseases in fungicide experiments. - Plant Disease Report 24: 340-343.

[34] Urrea, C. A., Miklas, P. N., Beaver, J. S. (1999): Inheritance of resistance to common bacterial blight in four tepary bean lines. - J. Amer. Soc. Hort. Sci. 124(1): 24-27.

[35] Vandemark, G. J., Fourie, D., Miklas, P. N. (2008): Genotyping with real-time PCR reveals recessive epistasis between independent QTL conferring resistance to common bacterial blight in dry bean. - Theor Appl Genet 117: 513-522.

[36] Yu, K., Park, S. J., Zhang, B., Havner, M., Poysa, V. (2004): An SSR marker in the nitrate reductase gene of common bean is tightly linked to a major gene conferring resistance to common bacterial blight. - Euphytica 138: 89-95.

[37] Zapata, M., Beaver, J. S., Porch, T. G. (2011): Dominant gene for common bean resistance to common bacterial blight caused by Xanthomonas axonopodis pv. phaseoli. Euphytica 179: 373-382. 